\title{
THE INFLUENCE OF VEGETATION ROOTS ON SLOPE STABILITY IN LANDSLIDE SUSCEPTIBLE AREAS
}

\author{
Ruwaida Zayadi \\ Doctoral Program in Environmental Science, Graduate School, \\ Brawijaya University, Malang, Indonesia \\ Zaenal Kusuma \\ Department of Soil Science, Faculty of Agriculture, \\ Universitas Brawijaya, Malang, Indonesia \\ Amin Setyo Leksono* \\ Departments of Biology, Faculty of Mathematics and Natural Sciences, \\ Universitas Brawijaya, Malang, Indonesia

\section{Bagyo Yanuwiadi} \\ Department of Biology, Faculty of Mathemathic and Natural Sciences, \\ Universitas Brawijaya, Malang, Indonesia \\ *Corresponding Author's e-mail: amin28@ub.ac.id
}

\begin{abstract}
Slope protection against shallow landslides using vegetation has been widely applied in civil and environmental engineering throughout the world, but its root role in slope stability has not been studied in Indonesia. This paper provides an indication of the mechanical strength parameters of several species of vegetation roots in the productive forest area on the hillside of Pujon, Malang Regency, East Java, Indonesia. Laboratory tests were conducted to evaluate the physical properties and shear strength of roots with roots and roots without roots [control]. The contribution of root strengthening to soil shear strength with respect to slope stability has been investigated by finite element analysis using Plaxis $2 D$ software. This approach allows quantification of the effect of mechanical root strengthening on slope safety factors and assessment of the sensitivity of slope stability to variations in the cohesion and depth of the root zone, $H_{r}[1$ and $2 \mathrm{~m}]$ and slope $[\alpha]$ between $15^{\circ}$ and $45^{\circ}$ with numerical simulations. This study showed that roots have shown to increase soil strength. The highest cohesion of the root-soil system was found in P. merkusii (12.03 $\left.\mathrm{kN} / \mathrm{m}^{2}\right)$, followed by A. dammara $\left(10.24 \mathrm{kN} / \mathrm{m}^{2}\right)$ and $T$. ciliata $\left(8.34 \mathrm{kN} / \mathrm{m}^{2}\right)$, the lowest was found in Eucalyptus sp. $\left(8.02 \mathrm{kN} / \mathrm{m}^{2}\right)$. Compared to the control those values were 66.8 to 100 times higher, and the average internal friction angle [ $\phi]$ decreased by $43 \%$ compared to rootless soil. The analysis showed that the effect of
\end{abstract}


root reinforcement on the FOS has increased 14 to $21 \%$ for both depths compare to the control. While that of $2 \mathrm{~m}$ depth increased 19 to $27 \%$ compare to the $1 \mathrm{~m}$. The results also showed that $P$. merkusii had the strongest roots, followed by A. dammara, T. ciliata, C. arabica and Eucalyptus sp.

Keywords: Landslide, Pinus merkusii, normal stress, shear strength, vegetation.

Cite this Article: Ruwaida Zayadi, Zaenal Kusuma, Amin Setyo Leksono and Bagyo Yanuwiadi, The Influence of Vegetation Roots on Slope Stability in Landslide Susceptible Areas. International Journal of Civil Engineering and Technology, 11(4), 2020, pp. 124-133. https://iaeme.com/Home/issue/IJCIET?Volume $=11 \&$ Issue $=4$

\section{INTRODUCTION}

The landslide is one of the disasters that has a high risk of human safety and may cause economic losses. In tropical climates, high rainfall acts as a trigger for landslides. This situation often worsens by human activities such as agriculture activities, construction of roads, buildings, dams, and deforestation. These activities alter land surface and vegetation that may reduce the natural ability to withstand landslides. The community's needs for fields and settlements have made the existing land, unable to sustain nature anymore.

One way to overcome landslides is to increase diversity of plants enable to strengthen slope [1]. Vegetation provides an important influence on the stability of hill slopes, because the root may strengthen the soil tension thereby increasing slope stability. Thus, the use of vegetation in reducing the vulnerability of land on the slopes to erosion and shallow landslides is an important consideration [2].

In areas with very high population density, such as in East Java, Indonesia, landslides also occur in various places, thus increasing the risk of accidents. The risk of landslides is magnified by changes in land use even in mountainous areas. Protection of natural and artificial slopes from shallow landslides with technology involving vegetation has been widely used throughout the world because past experience shows that the slopes under vegetation are more stable and resistant to erosion compared to bare slopes without vegetation $[3,4]$. However, changes in function can cause the slope to fail even though the natural slope has formed in a long period of time. Because it is necessary to replant regularly to improve slope stability as a preventive measure against landslides.

The use of vegetation to increase slope stability is an environmentally friendly, costeffective, simple and sustainable engineering measure [4,5]. Vegetation helps reduce erosion and susceptibility to shallow landslides due to mechanical and hydrological effects that affect soil properties $[6,7]$. Revegetation is an efficient measure of restoration measures on eroded land because they simultaneously control surface mass movements [2]. Vegetation through strengthening its roots may help prevent soil slippage and improve hillside stability $[7,8]$. Increased soil shear strength by roots directly through mechanical reinforcement, anchoring to the soil layer and forming a binding network in the layer, and indirectly through evaporation of water by transpiration [4]. Several studies reported that roots provide a reinforcing effect on the soil through tensile resistance and friction properties. Various types of root strengthening models have been developed to better understand the mechanism of strengthening soil slopes, because plant roots provide additional cohesion to the soil $[3,9,10]$.

Several studies have been carried out for three decades in various parts of the world by relevant experts such as geotechnical engineers, foresters, hydrologists, and other professionals to understand how vegetation can improve slope stability. With the beneficial effect of vegetation on slope stability, many studies have been carried out to measure the 
contribution of root strengthening to soil shear strength, including by direct laboratory shear tests on roots with soil [11]. The results showed that the shear strength due to root inclusion has increased mainly by the influence on cohesive interception, while the internal angle friction has little or no effect. However, verification is required by conducting laboratory tests to determine the shear strength of soil-root composites in undisturbed samples from different locations. Ground shear strength is a basic requirement in slope stability analysis. It is generally obtained by carrying out shear strength tests. Therefore, the increased soil shear strength due to root strengthening can be considered equivalent to the real increase in soil cohesion, $\left(c_{r}\right)$. As an analysis, the Mohr-Coulomb equation [12] for the shear strength of a root-soil composite [ $\tau \mathrm{r}]$ can be modified as follows [13].

$$
\tau_{\mathrm{r}}=\left[c+c_{r}\right]+\sigma \tan \phi
$$

Cohesion $[c]$ and internal friction angle $[\phi]$ of the soil are parameters that can be influenced by roots. The root strengthening effect can be expressed as an additional cohesion term $\left[c_{r}\right]$. Plant roots provide further cohesion to the soil and soil that absorbs roots so that it becomes stronger than if only the soil alone to survive soil damage procedures such as mass movements.

This study presents the findings of an evaluation analysis of the use of five vegetations as a strategy to reduce the activity of shallow landslides on the hillside in East Java, Indonesia. The objectives of this study were to determine the physical properties and shear strength of a soil composite system with roots and rootless soil using a direct shear test and to investigate and measure the effect of strengthening the roots of the five tree species on slope stability.

\section{RESEARCH METHODS}

Field study was conducted in Pujon District Production Forest managed by Perhutani (government own forest company), East Java Province, Indonesia. Geographically, this area

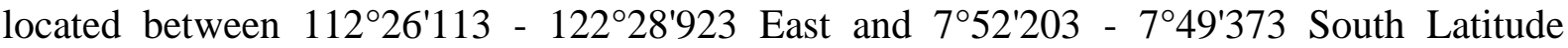
covering an area of 13,075,144 ha. Topography this area is a plateau that stretches from west to east or from north to south with an altitude between 1000-2500 m above sea level surrounded by mountains. Temperature range 18 to $23^{\circ} \mathrm{C}$ with an average rainfall of 21,400 $\mathrm{mm}$ per year. Soil texture according to the Unified Soil Classification System (USCS) is BC with $11.37 \mathrm{kN} / \mathrm{m} 3$ maximum dry density and $22.64 \%$ optimum moisture content. The soil strength parameters derived from the direct shear test for undisturbed soil samples results were $0.12 \mathrm{kPa}$ (cohesion, $c$ ) and $39.14^{\circ}$ [internal friction angle, $\phi$ ]. The slope of the Pujon District area is $59.53 \%$ of the site area with steep to very steep slopes [14]. Based on the data, the area had high risk of landslides, droughts and flash floods with 939.37 ha or $7.37 \%$ classified as critical potential and 705.97 ha or $5.54 \%$ fell as very critical was.

The soil samples were collected from surrounding of different plant species roots. The tree species studied were Agathis damara, Toona ciliata, Eucalyptus sp., Pinus merkusii and Coffea arabica. In the area, undisturbed soil samples were taken from two locations namely around trees for soils containing roots and slope areas without vegetation for rootless soils. Furthermore, from 5 points on 5 trees soil samples taken to a depth of $100 \mathrm{~cm}$ in the environment around each selected plant are between (25-50) $\mathrm{cm}$ from the tree trunk whose roots will be examined. After being positioned at the desired location, the soil is taken by inserting a cylindrical metal tube. The natural soil moisture (field humidity) of samples was maintained, by sealing the ends of the cylinders with paraffin. Samples were taken to the laboratory for testing in order to obtain physical properties and soil shear strength according to ASTM standards. Samples from cylinders collected were immediately tested by molding 3 to 4 specimens from each cylinder in the laboratory (diameter $6 \mathrm{~cm}$ and height $1.785 \mathrm{~cm}$ ). 
Collection and collection of rootless soil samples are carried out in the same way on slope locations without vegetation.

In the laboratory, molded soils were prepared for the direct shear test on natural moisture, i. e soil moisture. The test was carried out through the application of the normal force and horizontal force in relation to the sliding surface according to the ASTM D-3080 procedure. The normal forces applied to the specimen were: $4 \mathrm{~kg} ; 8 \mathrm{~kg}$ and $12 \mathrm{~kg}$. Three replications of direct shear test were carried out for each normal stress. Thus, each sample tube was made of 3 test specimens, with a total of 15 test specimens for soil with roots and 3 test specimens for without roots (control). For soil properties, test natural water content, according to ASTM D2216 procedure, density test, according to ASTM D-2937 procedure, specific gravity test according to ASTM D-854 procedure, sieve analysis, according to ASTM D-136 procedure, so that values obtained values such as: degree of saturation $\left(S_{r}\right)$, porosity $(n)$, pore number $(e)$, density $(\gamma s)$, specific gravity $\left(G_{s}\right)$ and dry density $(\gamma d)$.

\subsection{Slope Stability}

Evaluation of the contribution of vegetation through its roots to the stability of the slope to meet the safety factor requirements will be analyzed using the finite element method with the PLAXIS 2D V8 program with the "phi-c reduction" procedure [15]. This slope stability analysis method consists of successive reduction of soil shear resistance parameters (cohesion, internal friction angle) while maintaining a constant gravity load [16]. The soil mass strength parameters $[\tan \phi$ and $c]$ of the soil are successively reduced through the strength reduction factor until a slope collapse occurs, that is, a large deformation occurs in the soil mass with a slight decrease in the strength parameter. The power reduction factor in the "phi-c reduction" procedure is given as:

$$
M_{s f}=\frac{\tan \emptyset_{\text {input }}}{\tan \emptyset_{\text {rebound }}}=\frac{c_{\text {input }}}{c_{\text {rebound }}}
$$

Where

$M_{s f}=$ multiplier is used to define the reduced strength parameters at a given stage;

$\phi_{\text {input }}=$ the input friction angle;

$c_{\text {input }}=$ the input cohesion;

$\phi_{\text {rebound }}=$ the reduced friction angle at a given stage;

$c_{\text {rebound }}=$ is the reduced cohesion at a given stage.

The power reduction factor is set to 1.0 at the start of the calculation. The variation in the strength reduction factor by displacement at the nodal point close to the slope surface can be determined after calculation [17]. Slope failure can be checked whether the constant strength reduction factor is obtained when the deformation continues. The safety factor [FOS] of the slope is defined as the ratio of available soil strength compared to the strength of the land that is reduced at the time of failure and is given as follows:

$$
\text { FOS }=\frac{\text { Available strength }}{\text { Strength at failure }}=M_{\text {sf }} \text { at failure }
$$

In this study slope stability was investigated by changing the gradient of the slope $\left[15^{\circ}\right.$; $20^{\circ} ; 25^{\circ} ; 30^{\circ} ; 40^{\circ}$; and $45^{\circ}$ ] adjusted to the gradient in the study area with vegetation assumed to grow across the surface of the soil so that the thickness of the ground mass was rooted $1 \mathrm{~m}$ and $2 \mathrm{~m}$. The FOS value is calculated for rootless soil and soil with root. The increase in FOS due to root strengthening is also calculated as an increase in percentage and can be defined as follows [3]. 
increase of FOS $=100\left[\frac{\text { FOS }}{\text { with roots }-F O S_{\text {without roots }}} \underset{\text { FOS }}{\text { without roots }}\right]$

MS Excel 2010 software is used to analyze all data obtained from laboratory tests.

\section{RESEARCH RESULTS AND DISCUSSION}

\subsection{Soil Shearing Strength}

This study showed that roots have shown to increase soil strength. The highest cohesion of the root-soil system was found in $P$. merkusii $\left(12.03 \mathrm{kN} / \mathrm{m}^{2}\right)$, followed by $A$. dammara $(10.24 \mathrm{kN}$ $\left./ \mathrm{m}^{2}\right)$ and $T$. ciliata $\left(8.34 \mathrm{kN} / \mathrm{m}^{2}\right)$, the lowest was found in Eucalyptus $\mathrm{sp}$. $\left(8.02 \mathrm{kN} / \mathrm{m}^{2}\right)$. Compared to the control those values were 66.8 to 100 times higher (Table 1). Direct shear test studies of root-soil composite systems showed the trendlines relationship between normal-stress and shear-stress among soil sample from 5 plant spesies $(\tau-\sigma)$. The value of $\mathrm{r}^{2}$ was highest in C. arabica (0.9793), followed by $T$. ciliata (0.9362) and Eucalyptus sp. (0.9301), while that of control was 0.9998 (Figure 1). The effect root plant on soil strength was supported by reinforcing the cohesion force. The same situation has been studied with five plant species in China. In most of the literature, roots are considered to provide increased cohesion to the soil. However, there is no systematic change between the internal friction angle of the treatment and control. That meant, the results of the direct shear test showed that the internal friction angle for the root-composite system land was clearly similar to that of rootless soil [18]. Result showing the effect roots on the internal friction angle of the soil-root composite material were still very rare. Even in the triaxial tests conducted, another study reported conflicting conclusions regarding the effects of roots on soil resistance $[19,20]$. In one of the direct shear test results, the parallel displacement of the sliding envelope showed that the fiber does not affect the friction properties of the soil [for sample sand]. Interestingly, at normal stress range there was an increase in the internal friction angle [19].

The direct shear test in our study showed the results that when the cohesion of the rootsoil composite increases, the internal friction angle decreases. The direct shear test in this study produced an internal root friction angle without roots was $39.14^{\circ}$ while the average internal friction angle for five soil-composite composite systems was $22.27^{\circ}$, with the breakdown of each for trees (A. dammara $17.87^{\circ}$; T. ciliata $19,31^{\circ}$; Eucalyptus sp. $23,25^{\circ} ; P$. merkusii $25,36^{\circ} ;$ C. arabica $25,58^{\circ}$ ). There was a decrease in the internal friction angle of the root-soil composite system by $43 \%$ compared to rootless soil. This relatively states that the root allows reducing the soil shear strength by $43 \%$ through internal friction angles, but when $(c$ and $\phi$ ) is substituted as an input parameter to shear strength, the results will still increase because the increase in the percentage of cohesion values is much more significant $(98 \%)$. This corresponds to the parameter values of sandy soil strength following the trends described in the literature, which means that the root's main contribution to shear strength is mainly due to an increase in cohesive interception [21,22].

Table 1 Average soil and index properties at Pujon testing area, Malang, East Java Province, Indonesia

\begin{tabular}{llccccccccc}
\hline \multirow{2}{*}{ No. } & $\begin{array}{c}\text { Soil } \\
\text { condition }\end{array}$ & $\mathbf{g}_{\mathbf{s}}$ & $\mathbf{\mathbf { g } _ { \mathbf { d } }}$ & $\mathbf{w}$ & $\mathbf{n}$ & $\mathbf{e}$ & $\mathbf{G}_{\mathbf{s}}$ & $\mathbf{S}_{\mathbf{r}}$ & $\mathbf{C}$ & $\mathbf{f}$ \\
\hline \multirow{2}{*}{1} & Control & 13.91 & 11.37 & 22.64 & 54.4 & 27.69 & 2.494 & 46.74 & 0.12 & 39.14 \\
2 & P.merkusii & 11.56 & 9.03 & 47.65 & 63.3 & 35.36 & 2.601 & 66 & 12.03 & 25.36 \\
3 & A.dammara & 11.1 & 7.96 & 45.08 & 67.67 & 34.45 & 2.463 & 53.04 & 10.24 & 17.87 \\
4 & L.ciliata & 12.08 & 9.02 & 48.08 & 63.92 & 32.54 & 2.528 & 63 & 9.63 & 19.31 \\
5 & C. arabica & 13.05 & 9.03 & 44.69 & 63.92 & 32.54 & 2.5 & 63 & 8.34 & 25.58 \\
\multirow{2}{*}{6} & Eucalyptus & \multirow{2}{*}{10.86} & 7.36 & \multirow{2}{*}{47.45} & 69.09 & 35.17 & 2.38 & 50.67 & 8.02 & 23.25 \\
\hline
\end{tabular}


Ruwaida Zayadi, Zaenal Kusuma, Amin Setyo Leksono and Bagyo Yanuwiadi
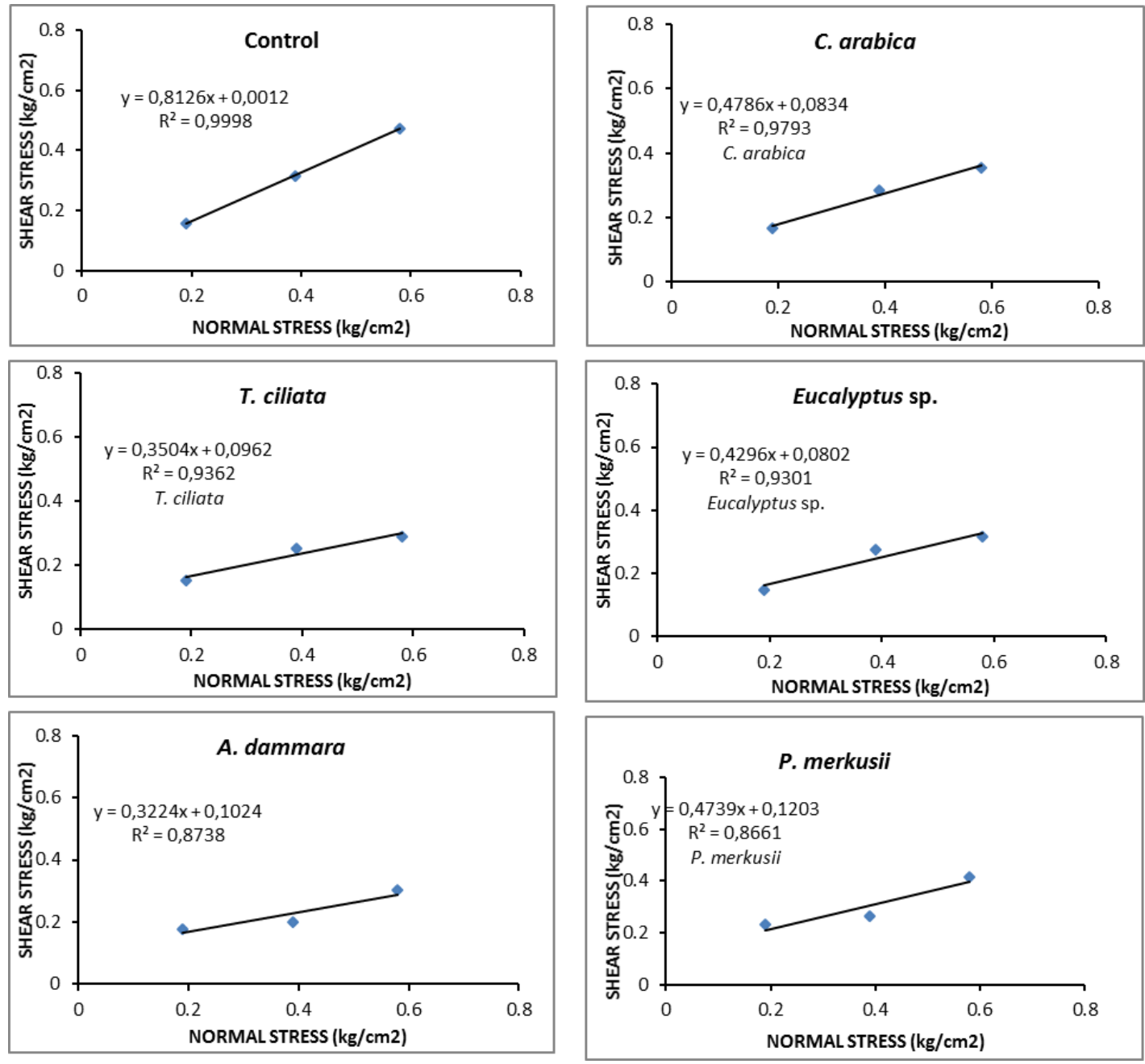

Figure 1. The relationship between shear strength $[\tau]$ and vertical pressure $[\sigma]$ for a soil-root and root composite soil system of the five plants. In this relationship, the cohesive strength of soil [c] is indicated by the intercept $y$, while the soil internal friction angle [f] is represented by the angle between the line and horizontal ordinate.

\subsection{Slope Stability}

Our results showed that the roots of the five trees were able to increase the stability of the slopes that were vulnerable to shallow landslides. At a slope between $15^{\circ}$ to $35^{\circ}$, the FOS value was above 1.25. these meant soil conditions was considered save. However, at a slope of $40^{\circ}$ or above, the FOS score on the control soil was 1.11, while those of the soil with plants were above 1.25. the highest FOS at 1-meter depth with slope of $40^{\circ}$ was found in P. merkusii (1.37), while the lowest was found in Eucalyptus sp. (1.25). At a slope of $45^{\circ}$, none of the FOS values were above 1.25. A similar situation is found at a depth of 2 meters. at a slope of $40 \mathrm{o}$ or above, the FOS score on the control soil was 1.11, while those of the soil with plants were above 1.25. the highest FOS at 2 meters depth with slope of $40^{\circ}$ was found in $P$. merkusii (1.48), while the lowest was found in C. arabica (1.25). at a slope of $45^{\circ} P$. merkusii merely has a FOS value above 1.25 (Table 2).

Safety factors for the analysis of the stability of permanent slopes such as cut and fill and repair of landslide slopes should be set to a minimum of 1.25 (Geotechnical Design Manual M46-03). Greater safety factors must be used when there is significant uncertainty in the input parameters for analysis. Substituting the cohesion parameter $(c)$ and the internal friction angle $(\phi)$ due to additional cohesion in the soil-root composite system in the calculation of FOS 
using the finite element method, the results show that FOS increases linearly with increasing cohesion and zone depth root. Simulation analysis is carried out by replacing rootless soils with soil containing roots to depths of $1 \mathrm{~m}$ and $2 \mathrm{~m}$. The results of previous studies showed that the highest FOS value when vegetation was applied to all land surfaces on the slope [23].

Table 2. Factor of safety [FOS] of soil with several roots' species

\begin{tabular}{|c|c|c|c|c|c|c|c|}
\hline \multirow{2}{*}{$\begin{array}{l}\text { Root } \\
\text { depth } \\
\text { [m] }\end{array}$} & \multicolumn{5}{|c|}{ with roots } & \multirow[b]{2}{*}{ Control } & \multirow[b]{2}{*}{ Slope $\left[^{\circ}\right]$} \\
\hline & P. merkusii & A. dammara & $\begin{array}{c}L . \\
\text { ciliata }\end{array}$ & $\begin{array}{c}C . \\
\text { arabica }\end{array}$ & $\begin{array}{c}\text { Eucalyptus } \\
\text { sp. }\end{array}$ & & \\
\hline \multirow{7}{*}{1} & 4.39 & 4.36 & 4.35 & 4.32 & 4.33 & 3.16 & 15 \\
\hline & 2.60 & 2.57 & 2.56 & 2.56 & 2.55 & 2.33 & 20 \\
\hline & 2.14 & 2.11 & 2.09 & 2.09 & 2.08 & 1.87 & 25 \\
\hline & 1.83 & 1.78 & 1.75 & 1.74 & 1.74 & 1.52 & 30 \\
\hline & 1.52 & 1.47 & 1.46 & 1.45 & 1.44 & 1.29 & 35 \\
\hline & 1.37 & 1.33 & 1.27 & 1.26 & 1.25 & 1.11 & 40 \\
\hline & 1.15 & 1.11 & 1.07 & 1.06 & 1.06 & 0.84 & 45 \\
\hline \multirow{7}{*}{2} & 4.54 & 4.43 & 4.34 & 4.16 & 4.17 & 3.16 & 15 \\
\hline & 2.79 & 2.73 & 2.70 & 2.69 & 2.68 & 2.33 & 20 \\
\hline & 2.34 & 2.26 & 2.21 & 2.20 & 2.20 & 1.87 & 25 \\
\hline & 2.01 & 1.92 & 1.87 & 1.84 & 1.87 & 1.52 & 30 \\
\hline & 1.73 & 1.66 & 1.60 & 1.59 & 1.59 & 1.29 & 35 \\
\hline & 1.48 & 1.40 & 1.35 & 1.34 & 1.36 & 1.11 & 40 \\
\hline & 1.30 & 1.22 & 1.17 & 1.08 & 1.17 & 0.84 & 45 \\
\hline
\end{tabular}

Our study indicated that the root-soil interaction may influence the soil stability in the hillside. The results of the direct shear test show that the shear strength of the root-soil composite system is higher than that of the rootless soil $[8,11,24,25,26]$.

With the influence of roots on the value of cohesion, increasing the value of this parameter is expected to play a role every time the root crosses the surface of the failure field. Splitting or slipping on the shear surface can be experienced by the roots of vegetation when experiencing shear forces [27]. The roots will increasingly contribute to the reinforcing element if the resistance to the two failure methods is higher. The deeper the root of the tree implanted beneath the soil, the greater the potential to avoid the movement of the topsoil, because it adds resistance to mechanically weaker layers [28]. This was consistent with our results that of soil depth $2 \mathrm{~m}$, the FOS values more than 1.25 for all observed slope angles $\left(15^{\circ}-40^{\circ}\right)$ (Table 3).

Simple models have been widely used to evaluate hillside vegetation stability by estimating additional cohesion due to the presence of roots [2,29]. Schmidt et al., 2001; Ji et al., 2012]. The effect of root strengthening of the five trees in the study area was calculated using this $\mathrm{Wu}$ model in slope stability analysis [12]. Wu, 1976]. The analysis showed that the effect of root reinforcement on the FOS has increased 14 to $21 \%$ for both depths compare to the control. While that of $2 \mathrm{~m}$ depth increased 19 to $27 \%$ compared to the $1 \mathrm{~m}$. This meant the deeper root lead to more stable soil. Therefore, some species had a great potential to increase soil strength and prevent the possibility of shallow landslides. The other study also stated that the increase in FOS depends on the values of $C_{r}$ and $H_{r}$. In general, FOS increases with $C_{r}$ and $H_{r}$ values with FOS results greater at $2 \mathrm{~m}$ than $1 \mathrm{~m}$ depths [23]. This was different from the results obtained by Abdi, [26] where FOS for root depth of $1 \mathrm{~m}$ was relatively more stable than that of $2 \mathrm{~m}$. the other study with diameters smaller than $20 \mathrm{~mm}$, this confirmed that the increase in FOS was relatively smaller in this study compared to the previous one $[4,26]$. An important result of the study is that the use of this vegetative strategy is not limited to sloping hill slopes, because this species can adapt well to steep hill slopes that are abundant in the 
District of Pujon, Malang Regency, East Java, Indonesia which require protection against shallow landslides.

\section{CONCLUSION AND RECOMENDATION}

This study showed that roots have shown to increase soil strength. The highest cohesion of the root-soil system was found in $P$. merkusii $\left(12.03 \mathrm{kN} / \mathrm{m}^{2}\right)$, followed by A. dammara $(10.24 \mathrm{kN}$ $\left./ \mathrm{m}^{2}\right)$ and T. ciliata $\left(8.34 \mathrm{kN} / \mathrm{m}^{2}\right)$, the lowest was found in Eucalyptus $\mathrm{sp}$. $\left(8.02 \mathrm{kN} / \mathrm{m}^{2}\right)$. Compared to the control those values were 66.8 to 100 times higher, and the average internal friction angle $[\phi]$ decreased by $43 \%$ compared to rootless soil. The analysis showed that the effect of root reinforcement on the FOS has increased 14 to $21 \%$ for both depths compare to the control. While that of $2 \mathrm{~m}$ depth increased 19 to $27 \%$ compare to the $1 \mathrm{~m}$. The results also showed that $P$. merkusii had the strongest roots, followed by A. dammara, T. ciliata, $C$. arabica and Eucalyptus sp. This information can eventually become part of the technical justification that ratifies the use of vegetation in increasing slope stability to prevent shallow landslides.

\section{ACKNOWLEDGEMENT}

The authors thank to Perhutani (state own forestry company) for supporting this research.

\section{REFERENCES}

[1] Genet M, Stokes A, Fourcaud T, Norris J. (2010) The influence of plant diversity on slope stability in a moist evergreen deciduous forest. Ecological Engineering. 36, 265-275

[2] Burylo M., Hudek C., \& Rey F. (2011) Soil reinforcement by the roots of six dominant species on eroded mountainous marly slopes (Southern Alps, France). Catena. 84, 70-78. https://doi.org/10.1016/j.catena.2010.09.007

[3] Genet M., Kokutse N., Stokes A., Fourcaud T., Cai X., Ji, J., \& Mickovski, S. (2008) Root reinforcement in plantations of Cryptomeria japonica D. Don: effect of tree age and stand structure on slope stability. Forest Ecology and Management. 256, 1517-1526. https://doi.org/10.1016/j.foreco.2008.05.050

[4] De Baets S., Poesen J., Reubens B., Wemans K., De Baerdemaeker J., \& Muys B. (2008) Root tensile strength and root distribution of typical Mediterranean plant species and their contribution to soil shear strength. Plant and Soil. 305, 207-226. https://doi.org/10.1007/s11104-008-9553-0

[5] Wu T.H., Kokesh C. M., Trenner B. R., \& Fox P. J. (2014) Use of live poles for stabilization of a shallow slope failure. Journal of Geotechnical and Geoenvironmental Engineering. 140(10), 1-13. https://doi.org/10.1061/(ASCE)GT.1943-5606.0001161

[6] Schmidt K. M., Roering J. J., Stock J. D., Dietrich W. E., Montgomery D. R., \& Schaub T. (2001) The variability of root cohesion as an influence on shallow landslide susceptibility in the Oregon Coast Range. Canadian Geotechnical Journal. 38, 995-1024 https://doi.org/10.1139/cgj-38-5-995

[7] Stokes A., Atger C., Bengough A.G. et al. (2009) Desirable plant root traits for protecting natural and engineered slopes against landslides. Plant Soil. 324, 1-30 https://doi.org/10.1007/s11104-009-0159-y

[8] Nilaweera N. S., \& Nutalaya P. (1999) Role of tree roots in slope stabilisation. Bulletin of Engineering Geology and the Environment. 57, 337-342. https://doi.org/10.1007/s100640050056

[9] Abdullah M. N., Osman N., Ali F. H. (2011) Soil-root shear strength properties of some slope plants. Sains Malaysiana; 40(10), 1065-1073.

https://iaeme.com/Home/journal/IJCIET 131 editor@iaeme.com 
[10] Mao Z., Jourdan C., Bonis M. L., Pailler F., Rey H., Saint-André L., \& Stokes A. (2013) Modelling root demography in heterogeneous mountain forests and applications for slope stability analysis. Plant and Soil. 45, 56-69. https://doi.org/10.1007/s11104-012-1324-2

[11] Waldron, L. J., \& Dakessian, S. (1981) Soil reinforcement by roots: Calculation of increased soil shear resistance from root properties. Soil Science. 132 p 427-435 https://doi.org/10.1097/00010694-198112000-00007

[12] Wu T.H. (1976) Investigation of landslides on Prince of Wales Island, Alaska. Geotechnical Engineering Report 5, Ohio State University, Department of Civil Engineering.

[13] Coppin, N., \& Richards I.G. (1990) Construction Industry Research \& Information Assoc. London, England.

[14] Muttaqin T. (2014) Evaluasi Kekritisan Lahan di Kawasan Lindung Kecamatan Pujon Kabupaten Malang Jawa Timur dengan Teknologi Sistem Informasi Geografis. Jurnal Gamma. 10, 135 - 142.

[15] Brinkgreve, R. B. J., Swolfs W. M., Engin E., Waterman D., Chesaru A. (2010) User manual, Plaxis bv.

[16] Kokutse N. K., Temgoua A. G. T., \& Kavazović Z. (2016) Slope stability and vegetation: Conceptual and numerical investigation of mechanical effects. Ecological Engineering. 86, 146-153. https://doi.org/10.1016/j.ecoleng.2015.11.005

[17] Fan C.C., \& Lai Y.F. (2014) Influence of the spatial layout of vegetation on the stability of slopes. Plant Soil.

[18] Hu X., Brierley G., Zhu H. et al. (2013) An exploratory analysis of vegetation strategies to reduce shallow landslide activity on loess hillslopes, Northeast Qinghai-Tibet Plateau, China. Journal of Mountain Science. 10, 668-686 (). https://doi.org/10.1007/s11629-0132584-x

[19] Graf F., Frei M., \& Böll A. (2009) Effects of vegetation on the angle of internal friction of a moraine. Forest Snow and Landscape Research. 82(1), 61-77.

[20] Zhang C. B., Chen L. H., Liu Y. P., Ji X. D., \& Liu X.P. (2010) Triaxial compression test of soil-root composites to evaluate influence of roots on soil shear strength. Ecological Engineering. 36, 19-26. https://doi.org/10.1016/j.ecoleng.2009.09.005

[21] Wu T.H., \& Watson A. (1998) In situ shear tests of soil blocks with roots. Canadian Geotechnical Journal. 35, 579-590 https://doi.org/10.1139/t98-027

[22] Veylon G., Ghestem M., Stokes A., \& Bernard A. (2015) Quantification of mechanical and hydric components of soil reinforcement by plant roots. Canadian Geotechnical Journal. 52(11), 1839-1849. https://doi.org/10.1139/cgj-2014-0090

[23] Chok Y. H., Jaksa M. B., Kaggwa W. S., \& Griffiths D. V. (2015) Assessing the influence of root reinforcement on slope stability by finite elements. International Journal of GeoEngineering. 6(12), 1 - 13. https://doi.org/10.1186/s40703-015-0012-5

[24] Operstein V., \& Frydman S. (2000) The influence of vegetation on soil strength. Ground Improvement 4, 81-89. https://doi.org/10.1680/grim.2000.4.2.81

[25] Ekanayake J. C., \& Phillips C. J. (2002) Slope stability thresholds for vegetated hillslopes: A composite model. Canadian Geotechnical Journal. 39, 849-862. https://doi.org/10.1139/t02-026

[26] Abdi E. (2014). Effect of Oriental beech root reinforcement on slope stability (Hyrcanian forest, Iran). Journal of Forest Science. 60(4), 166-173. 
[27] Maffra C., Sousa R., Sutili F., \& Pinheiro R. (2019) The Effect of Roots on the Shear Strength of Texturally Distinct Soils. Floresta e Ambiente. 26(3), 1 - 11. e20171018 https://doi.org/10.1590/2179-8087.101817

[28] Schwarz, M., Preti, F., Giadrossich, F., Lehmann, P., \& Or, D. (2010) Quantifying the role of vegetation in slope stability: A case study in Tuscany (Italy). Ecological Engineering. 3, 285-291. https://doi.org/10.1016/j.ecoleng.2009.06.014

[29] Ji J., Kokutse N., Genet M., Fourcaud T., \& Zhang Z. (2012) Effect of spatial variation of tree root characteristics on slope stability. A case study on Black Locust (Robinia pseudoacacia) and Arborvitae (Platycladus orientalis) stands on the Loess Plateau, China. Catena. 92, 139-154 https://doi.org/10.1016/j.catena.2011.12.008 